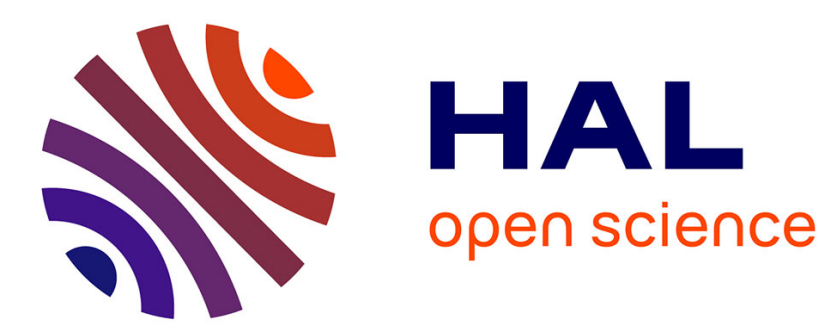

\title{
Interplay between local and international journals: The case of Sicily, 1880-1920 \\ Rossana Tazzioli
}

\section{To cite this version:}

Rossana Tazzioli. Interplay between local and international journals: The case of Sicily, 1880-1920.

Historia Mathematica, 2018, 45 (4), pp.334-353. 10.1016/j.hm.2018.10.006 . hal-02265916

\section{HAL Id: hal-02265916 https://hal.science/hal-02265916}

Submitted on 12 Aug 2019

HAL is a multi-disciplinary open access archive for the deposit and dissemination of scientific research documents, whether they are published or not. The documents may come from teaching and research institutions in France or abroad, or from public or private research centers.
L'archive ouverte pluridisciplinaire HAL, est destinée au dépôt et à la diffusion de documents scientifiques de niveau recherche, publiés ou non, émanant des établissements d'enseignement et de recherche français ou étrangers, des laboratoires publics ou privés. 
archives-ouvertes

\section{Interplay between local and international journals: The case of Sicily, 1880-1920 \\ Rossana Tazzioli}

\section{To cite this version:}

Rossana Tazzioli. Interplay between local and international journals: The case of Sicily, 1880-1920.

Historia Mathematica, Elsevier, 2018, 45 (4), pp.334-353. 10.1016/j.hm.2018.10.006 . hal-02265916

\section{HAL Id: hal-02265916 \\ https://hal.archives-ouvertes.fr/hal-02265916}

Submitted on 12 Aug 2019

HAL is a multi-disciplinary open access archive for the deposit and dissemination of scientific research documents, whether they are published or not. The documents may come from teaching and research institutions in France or abroad, or from public or private research centers.
L'archive ouverte pluridisciplinaire HAL, est destinée au dépôt et à la diffusion de documents scientifiques de niveau recherche, publiés ou non, émanant des établissements d'enseignement et de recherche français ou étrangers, des laboratoires publics ou privés. 


\section{Rossana Tazzioli}

\section{Keywords}

Giovan Battista Guccia, Sicilian journals, Rendiconti del Circolo Matematico di Palermo

\section{Abstract}

In 1884, Giovan Battista Guccia founded first the Circolo Matematico di Palermo and then some years later its journal, the Rendiconti del Circolo Matematico di Palermo. Although historians of mathematics have published a number of works on the Circolo and the Rendiconti, there are very few systematic studies on mathematics in Sicilian periodicals. In our paper, we shall investigate the relationships between the "international" Rendiconti and the "local" proceedings published by the Sicilian academies located in Catania, Messina, and Palermo. What is the image of mathematics that emerges from these journals? What is the presence of Sicilian mathematicians among the authors in the different cases? May we recognize a Sicilian dynamics in mathematics and, if so, in what sense?

\section{Introduction}

In 1884, when Giovan Battista Guccia founded first the Circolo Matematico di Palermo and then some years later its journal, the Rendiconti, there were already a number of other periodicals in existence in Sicily which also contained articles on mathematical subjects. Mathematical papers were in fact published in the proceedings (Atti) of several Sicilian academies, some of which date back to the 17th century. In general, Sicilian academies had a vocation to develop science, humanities and the arts, so their proceedings contained a wide spectrum of topics, from history to poetry, botany and science, and mathematics played a not inconsiderable role. The audience of the Atti was quite large, though mostly academic: university professors, teachers, and intellectuals in general. The Jahrbuch über die Fortschritte der Mathematik ${ }^{l}$ reviewed these journals, bringing them to the attention of all professional mathematicians.

Although the proceedings of the Sicilian academies are 'local' journals, they constitute an interesting object of study, especially because of their interplay with the 'international' Rendiconti. They contain indeed a large quantity of mathematics. For instance, Atti dell'Accademia Gioenia di Scienze Naturali of Catania is the journal of a scientific academy that mostly contains articles on natural sciences linked to Mount Etna, its history, geology and eruption activity, yet it also published 114 mathematical papers between 1880 and 1920. Our research aims to illustrate mathematical transmission through Sicilian journals by focusing on the interplay between the Rendiconti and the various Atti. In particular, we shall analyze the mathematical papers published in these journals - including mathematical

\footnotetext{
${ }^{1}$ Concerning the Jahrbuch über die Fortschritte der Mathematik and its reviewing practices, cf. also the paper by Hélène Gispert in this issue.
} 
research, training, teaching, and popularization - as well as their authors and audience. We will not take into account those papers in which mathematics was merely applied to other subjects. The period at issue, 1880-1920, covers the years from the creation of the Circolo Matematico to the beginning of the interwar period.

For our analysis, we shall consider all the authors of mathematical papers published in the Atti and try to answer the following questions:

(i) The authors were mostly university professors, mathematics teachers, and students, but who were they in particular? Were they located in Sicily? Did they ever leave Sicily during their careers, or did they only work in Sicily?

(ii) In their mathematical papers, did the authors mention local, national or international publications? Did they publish in both the Atti and the Rendiconti, and more generally in other national or international journals?

(iii) What was the audience of these journals? Who actually read these mathematical papers (university professors, secondary school teachers, or students)?

(iv) What about the mathematical topics? Were they research or elementary topics? Did they deal with new or already established disciplines?

Our analysis, which focuses on the mathematical papers published in the Atti of the Sicilian academies, will allow us to answer several questions related to Sicilian mathematics and, more generally, to the transmission of mathematics through journals.

We distinguish three main periods during which we give an account of Sicilian universities, the role of mathematics and mathematicians in Sicilian academies and their journals, and the interplay of Sicilian journals, in particular between the Atti and the Rendiconti. During the first period (1880-1890), Guccia founded the Circolo and the Rendiconti; at the time, the University of Palermo was the only university that actually awarded degrees in mathematics in Sicily. During the second period (1891-1908), all three Sicilian universities could award degrees in mathematics; the Rendiconti became a reputed mathematical journal, and in the Atti the publication of mathematical papers increased. The last period (1909-1920) starts just after the earthquake in Messina and the International Congress of Mathematicians (Rome, 1908) that marked the true internationalization of the Rendiconti; in this section we trace the different histories of the various academies and their Atti, and point out their connections to the Rendiconti. A final paragraph contains concluding remarks. Annexes 1,2 and 3 provide information supporting some crucial points of our research: a list of professors at Sicilian universities in the period 1880-1920 (Annex 1); a list of all the authors of mathematical papers in the proceedings of Sicilian academies, with the number of papers they published in the Atti, in the Rendiconti and in other (Italian or foreign) journals (Annex 2); the number of mathematical papers published in the Atti of Sicilian academies in significant time periods (Annex 3). ${ }^{2}$

\footnotetext{
${ }^{2}$ Further biographical information about the authors who published in the Atti can be found on the website https://cirmath.hypotheses.org/les-outils-de-cirmath/materiaux-supplementaires-pour-levolume-interplay-between-journals-at-various-scales-historia-mathematica-2018
} 


\section{Mathematical institutions and journals in Sicily, 1880-1890}

In 1861, the Unification of Italy, which had previously been divided in various smaller States, was completed. Victor Emmanuel II, already King of Sardinia-Piedmont, became the first King of Italy. For Italian higher education, the Casati Law of $1859^{3}$ and its amendments of 1862 signed by Matteucci were of considerable importance. ${ }^{4}$ This law divided Italian universities into two categories, depending on their rating: Bologna, Naples, Palermo, Pavia, Pisa and Turin belonged to the first category, Genoa, Catania, Messina, Modena, Parma and Siena to the second. This distinction had enormous consequences on public funding for universities. The lack of adequate financial support prevented the universities of Catania and Messina from providing all the university courses necessary for obtaining a degree in mathematics - at that time the full university course in mathematics lasted four years and a tesi di laurea (thesis) on a special subject was required for graduation. As a result, these universities were not allowed to award degrees in mathematics. Sicily's Government and local administrations provided the necessary support to promote them to the first category of Italian universities. As a result, in 1885 the Italian Government promulgated the "equalization law" (legge di pareggiamento), which placed the universities of Catania and Messina in the top category. ${ }^{5}$ In 1886 they were able to employ professors to provide new university courses and subsequently award degrees in mathematics. Nevertheless, it was only at the turn of the century that the universities of Catania and Messina attained a good level in mathematics.

The history of mathematics at the University of Palermo was different from that of Catania and Messina. In fact, the top category of universities had included the University of Palermo from the time of the Unification of Italy. Moreover, in 1868 the Scuola di Applicazione per gli Ingegneri (a kind of modern Polytechnic School) was founded in Palermo and gave a big boost to mathematical studies. In 1881 Alfredo Capelli, a young and brilliant mathematician was appointed professor at the University of Palermo. He had graduated from the University of Rome and spent some time in Berlin with Weierstrass, Kummer, Frobenius and Kronecker ${ }^{6}$. He mainly contributed to group theory and to invariant theory. When he moved to the University of Naples in 1886, he was replaced by Ernesto Cesaro. Cesaro, who had studied in Italy, France and Belgium, was a specialist in number theory, analysis and mathematical physics.

Mathematical research in Palermo and throughout Sicily was boosted by the foundation of the Circolo Matematico by Guccia in $1884 .{ }^{7}$ Guccia was an algebraic geometer, one of

\footnotetext{
We point out that all the authors of mathematical papers published in Atti belonged to Sicilian institutions. ${ }^{3}$ Law of November $13^{\text {th }} 1859$, N. 3725. On this law and its influence on mathematic education, see [Giacardi 2006].

${ }^{4}$ Law of July $31^{\text {st }} 1862$, N. 719.

${ }^{5}$ Coppino Law of December $13^{\text {th }} 1885$, N. 2572.

${ }^{6}$ The mobility of individual mathematicians is an important aspect of the circulation of mathematics, which will be met with in most papers of this issue.

${ }^{7}$ On the Circolo Matematico di Palermo see [Brigaglia and Masotto, 1982].
} 
Cremona's students at the University of Rome, where he graduated in 1880 . He came back to Palermo the same year and became professor at the University there in 1889. His aim was to raise the mathematical level at the University of Palermo, which was rather low at the time, and more generally create a mathematical elite in Sicily. In order to achieve his goal, Guccia wanted the Circolo to be an actual international society and the reference point for all Italian mathematicians. ${ }^{8}$ Guccia faced many difficulties in pursuing his project, as he did not have any significant external financial or institutional support either locally or nationally. He used his family fortune to support the Circolo and Rendiconti. His disdain for localism and the academies (Sicilian and not) clearly emerges in a letter he wrote to Volterra on December $4^{\text {th }}$ 1887:

"I am afraid we Italians are much at fault in not giving value to our scientific publications. We keep them locked away, hidden, so that foreigners are never able to know and appreciate them. Furthermore, our Academies, in the way they are directed and managed, give sacred burial to the works published in their proceedings." 9

To escape localism and national interests, Guccia increasingly opened his Circolo and the Rendiconti to foreign mathematicians, although it was to take about twenty years for the Circolo and its journal to become truly international ${ }^{10}$. The first volume of the Rendiconti appeared in 1887. The editorial board of 1888 was representative of all Italian mathematical schools and traditions. It was composed of five members from Palermo (Giuseppe Albeggiani, Francesco Albeggiani, Francesco Caldarera, Michele Gebbia and Guccia) and fifteen from the rest of Italy; however, there were no foreign members on the editorial board. The editor-in-chief of the Rendiconti was the director of the Circolo. In the first volume, "Sicilian" authors, i.e. mathematicians belonging to a Sicilian university, wrote 12 of the 22 papers. ${ }^{11}$ Until 1890, most of the authors of articles in the Rendiconti were from Sicily, and more particularly from Palermo (F. Caldarera, 4 articles) and Messina (Marcolongo, 1 article; Martinetti, 1 article; Vivanti, 10 articles). Nevertheless, the number of foreign authors increased over the years, especially from France. Guccia was in fact in close contact with French mathematicians and had a special friendship with Poincaré. This growing international opening-up is evident in an analysis of subsequent issues of the Rendiconti, and we shall return to this question in sections 3 and 4 .

\footnotetext{
8 See [Brigaglia, 2014].

9 This letter is kept in the Volterra Archive in the library of the Accademia dei Lincei in Rome. The original reads as follows: "Noi italiani, mi perdoni, abbiamo il gran difetto di non saper far valere la nostra produzione scientifica, la teniamo sotto chiave, nascosta, per modo e guisa che gli stranieri non riescano mai a conoscerla ed apprezzarla. Del resto le Accademie nostre, tali come sono dirette e amministrate, per la maggior parte, provvedono benissimo a dare degna sepoltura ai lavori inseriti nei loro Atti."

${ }^{10}$ Internationalism is a notion which can cover various meanings as we will see throughout the papers in this issue.

11 In particular: Michele Albeggiani (2 papers), Ernesto Cesaro (4 papers), Ignazio Conti, Michele Gebbia, Francesco Gerbaldi, Guccia (2 papers), Vincenzo Martinetti.
} 
What were the Sicilian academies and their Atti that Guccia harshly criticized when he founded the Circolo? What impact did they have on Sicilian mathematics?

In the period 1880-1891 the following academies existed in Sicily (and most of them still exist now): the Accademia delle Scienze, Lettere, e Arti in Palermo, the Accademia di Scienze, Lettere e Arti dei Zelanti e PP. dello Studio and the Accademia Dafnica in Acireale, the Accademia Peloritana dei Pericolanti in Messina, and the Accademia Gioenia di Scienze Naturali in Catania.

In this section we illustrate the publications, and especially mathematical papers, of these academies (Atti), as well as their authors and readers.

The Accademia delle Scienze, Lettere, e Arti di Palermo was founded in 1718, as the continuation of the Accademia degli Accesi (16th century) and Accademia dei Riaccesi (17th century). In 1859 two professors of the University of Palermo, Francesco Caldarera, professor of mechanics and later the president of the Circolo Matematico di Palermo, and Giuseppe Albeggiani, professor of calculus, became members of the Palermo Academy. In 1900 Guccia himself, already the director of the Circolo Matematico, became the secretary of the Academy, and in 1910 a member of the Gioenia Academy.

The journal, Atti dell'Accademia di Scienze, Lettere, e Arti (AAPalermo), began publication in 1845. We shall not take into consideration the Atti of the Palermo Academy in our research, since no mathematical paper appeared in the journal with the aim of improving mathematical research or teaching, or even of popularizing mathematics. We would nevertheless point out that the Atti contained several papers on geodesy and astronomy, in which mathematics is a research tool.

Acireale is a town near Catania; in the 17th century it became a very rich center especially for trade; the town was also a bishopric. In 1671 the clergy founded the Accademia degli Zelanti in order to help religious, priests and the clergy in general to make progress in science, and to promote the study of rhetoric and philosophical and moral questions, as well as the culture of Latin and Italian. ${ }^{12}$

In 1712 another religious academy was created, the Congregazione dei Padri dello Studio. Four clerics - called Padri dello Studio - were at the head of the Congregazione; they were also members of the Accademia degli Zelanti.

In 1778 the jurist Michelangelo Amico founded a secular academy, the Accademia dei Geniali, which took the name of Accademia dei Dafnici in $1816 .{ }^{13}$ The secular and dynamic institution aimed at giving impetus to letters and arts, by promoting meetings and awards. Around the same time, two new institutions arose in Acireale - a school for teaching literature

\footnotetext{
${ }^{12}$ For the history of Acireale's academies, see [Cosentini, 1970], [Donato, 2003].

13 "Zelanti" means "men of zeal", while in Greek mythology the term "Dafnici" comes from Daphnis, a Sicilian shepherd who was said to be the inventor of the pastoral poetry. Longus refers to it in his novel Daphnis and Chloe (2nd century AD), see [Reeve 1982].
} 
in the Church of Filippini and the private school Collegio degli Studi, called "Gulli and Pennisi", directed by Jesuits.

Three cultural academies were too many for a small - albeit rich - town such as Acireale. In 1834 the Accademia degli Zelanti merged with the Congregazione dei Padri dello Studio and changed the name to the Accademia di Scienze, Lettere e Arti dei Zelanti e PP. dello Studio di Acireale (we shall call it the Accademia degli Zelanti for brevity). The philosopher Lionardo Vigo Calanna and the mathematician Lorenzo Maddem strongly involved themselves in improving the new institution. In 1934 the Accademia degli Zelanti and the Accademia dei Dafnici merged, giving rise to the new Accademia di Scienze, Lettere e Belle Arti degli Zelanti e dei Dafnici, which still exists today.

In the period 1880-1920 there were two academies in Acireale - the Accademia degli Zelanti was more interested in science than the secular Accademia dei Dafnici, perhaps because of the involvement of scientists in its academic life, particularly mathematicians being professors or liberi docenti at the University of Catania. ${ }^{14}$ Furthermore, teachers of secondary schools ${ }^{15}$ as well as some non-local mathematicians, such as the future president of the Circolo Matematico Francesco Caldarera (University of Palermo) from 1856 and Roberto Marcolongo (University of Messina) from 1905, and the secondary school teacher Aureliano Faifofer (Liceo of Venice) from 1908, were all members of the Accademia degli Zelanti. We point out that Gaetano Caldarera was a geometer, one of Pieri's students, while Biffignandi and Sebastiano Catania were in contact with the Peano School. ${ }^{16}$

No mathematician was a member of the Accademia dei Dafnici, which began its proceedings (Atti e rendiconti dell'Accademia dei Dafnici, AADafnici) in 1892. The papers published by this Academy mainly concern literature, poetry, and philosophy, although some also concerned natural sciences, zoology and biology. Before 1920, only three papers with any mathematical content were published. The Atti e rendiconti dell'Accademia degli Zelanti (AAZelanti) appeared in 1889: the journal contained eleven mathematical papers up to 1920. In the period 1880-1890 only one mathematical paper appeared in AAZelanti: the author was Biffignandi and the paper illustrated the theory of proportions based on the fifth book of Euclid's Elements [Biffignandi, 1890].

The Accademia Peloritana dei Pericolanti was created in Messina in $1729 .{ }^{17}$ It was the continuation of other academies that dated back to the 16 th century. ${ }^{18}$ Several mathematicians

\footnotetext{
14 We mention the following members: Maddem from 1832; Giuseppe Zurria from 1857; Vincenzo Amato, Michele Cipolla and Giuseppe Marletta from 1916; Ermenegildo Daniele from 1918.

15 We mention Augusto Biffignandi, Alfio Fichera, Gaetano Caldarera, and Sebastiano Catania.

${ }_{16}$ Augusto Biffignandi wrote five letters to Giuseppe Peano from 1891 to 1897; see the Fondo Giuseppe Peano at the Biblioteca Civica di Cuneo. Catania published several textbooks for secondary schools in which he followed Peano's ideas of the Formulario Mathematico. See for instance [Catania 1906, 1908]. On the Peano School, see also the paper by Luciano in this issue.

17 The term "pericolanti" (literally "unsafe") comes from the fact, evoked by the first perpetual secretary of the Academy, Abbot Carlo Vitali, that the scholar navigates with difficulty between the obstacles and controversies of knowledge as the navigator is in danger by crossing the Strait of Messina.

18 On the history of the Accademia Peloritana dei Pericolanti, see [Oliva, 1916], [Novarese, 2011].
} 
were members of this academy and some also belonged to the chief committee. In the period 1880-1890 the mathematician Gian Antonio Maggi, professor of calculus at the University of Messina, became the secretary of the Messina Academy, and two of his colleagues at the university, the geometers Giovanni Maisano and Vittorio Martinetti, were members of the Academy. The Atti dell'Accademia Peloritana dei Pericolanti (AAPeloritana) did not publish any mathematical papers until 1898.

The Accademia Gioenia di Scienze Naturali di Catania was founded in $1824 .{ }^{19}$ Its main aim was to develop research on natural sciences, which was particularly fruitful and lively in Catania and its surrounding area because of the presence of the largest active volcano in Europe, Mount Etna. The involvement of the University of Catania was remarkable for the financial and logistical support and the commitment of many university professors in the life of the Gioenia Academy. ${ }^{20}$

The Accademia Gioenia was the only scientific academy in Sicily. From the beginning it was divided into two classes: natural sciences with special regard to Sicily, and physical sciences aiming at analyzing astronomical and meteorological observations in various places on the island, phenomena due to Mount Etna, and "everything that affects human physical constitution". ${ }^{21}$ Mathematics thus entered into the two sections only indirectly, as the most appropriate instrument for studying the laws of nature. "Calculations often shorten the efforts and the path of the naturalist", wrote the secretary of the Academy Domenico Orsino in 1844. ${ }^{22}$ For instance, the mathematician Giuseppe Zurria, who made some interesting contributions to calculus and celestial mechanics, was the director of the Academy from 1882 to 1896; the Academy's secretary was Vincenzo Mollame (1887; 1889-1891), professor of algebra and geometry at the University of Catania. In the period 1880-1890, three professors of mathematical sciences became members of the Gioenia Academy. ${ }^{23}$

The Accademia Gioenia began publishing the Atti dell'Accademia Gioenia di Scienze Naturali di Catania (AAGioenia) in 1825. Another publication, the Bollettino Mensile delle Sedute dell'Accademia Gioenia di Scienze Naturali di Catania, appeared in 1888 and was followed by the Bollettino delle Sedute dell'Accademia Gioenia di Scienze Naturali in 1893 (BAGioenia). While the Atti published scientific papers, including mathematical papers, the Bollettino usually contained an account of academic sessions and a brief summary (sometimes only the title) of memoirs that afterwards appeared in other journals. We shall not take these notes into account.

\footnotetext{
19 The Academy was named Gioenia after the famous naturalist and volcanologist from Catania Giuseppe Gioeni (1743-1822).

20 On the history of the Accademia Gioenia, its objectives and links to the university, and the cultural and social life of Catania, see the commemorative volume [Alberghina, 2005]. In this volume [Tazzioli, 2005] focuses on mathematics at the Accademia Gioenia.

21 In Atti dell'Accademia Gioenia, vol. 1, 1825, p. V-VI.

22 In Atti dell'Accademia Gioenia, S. 3, vol. 1, 1844, p. 26.

23 Vincenzo Amato, Lorenzo Maddem, and Giovanni Pennacchietti.
} 
In the Atti dell'Accademia Gioenia, several mathematical papers appeared. The authors were mainly Sicilian mathematicians - university professors, mathematics teachers at secondary schools, or students at the University of Catania who published excerpts from their theses. From 1880 to 1890 , eleven mathematical papers appeared in the AAGioenia, and Mollame wrote five of them. We would point out that all the authors taught at the University of Catania or were local secondary school teachers.

As already mentioned, although Sicilian academies published periodicals not specialized in mathematical topics, all their proceedings - except for AAPalermo that does not contain any mathematical papers (see above) - were remarkably taken into account in the database of the Jahrbuch über die Fortschritte der Mathematik.

To conclude, in the period 1880-1890 the Universities of Catania and Messina were rather weak, particularly with regard to mathematical studies, although there were a number of interesting characters. The lack of mathematical articles in the Sicilian Atti corroborates this argument. An exception is the AAGioenia, where Vincenzo Mollame, who was not originally a mathematician, was the main author of mathematical articles.

Mathematics at the University of Palermo was better, though not brilliant. Creating a true Sicilian mathematical community was in fact the main reason why Guccia founded the Circolo Matematico and the Rendiconti, and tried to make them as internationally attractive as possible. However, in these early years the Rendiconti did not escape localism.

\section{The golden age of Sicilian mathematics: 1891-1908}

Thanks to the equalization law in 1885, the Universities of Catania and Messina were able to offer a full graduate program in mathematics and employ new mathematics professors. In Messina and Catania, the first degrees in mathematics were awarded in 1891 and in 1895 respectively. ${ }^{24}$ At the turn of the 20th century some excellent non-local mathematicians were appointed professors at the University of Catania. Mario Pieri, a specialist in projective geometry and enumerative algebraic geometry who also contributed to the foundations of geometry as a representative member of the Peano School, was in Catania from 1900 to 1908 and supervised several theses. ${ }^{25}$ Another geometer was Giuseppe Marletta, one of Pieri's students, who taught at the University of Catania as assistant professor from 1901 onwards and became university professor in 1920. Pieri published just two papers in the AAGioenia, but his students and especially Marletta were very prolific authors in the Atti of Sicilian journals.

Analysis and mathematical physics were also well represented in Catania, as well as geometry and algebra, thanks to the Sicilian Giuseppe Lauricella, who graduated from the University of Pisa and in 1898 moved to Catania where he was appointed professor and died prematurely in

\footnotetext{
${ }^{24}$ For mathematics at the University of Catania, see [Tazzioli, 1999]; for the University of Messina, see the Annuario dell'Università di Messina (1880-1920).

${ }^{25}$ For Pieri's work and his legacy at the University of Catania, see [Marchisotto, 2007].
} 
1909. In 1907 the prestigious Società Italiana delle Scienze (detta dei XL) awarded its gold medal to Lauricella for his memoirs on the existence theorem for elasticity equations. In the same year Lauricella won the Prix Vaillant of the Paris Academy of Sciences. Guido Fubini (in Catania from 1902 to 1905) and Carlo Severini (in Catania from 1905 to 1914), both analysts and colleagues of Lauricella, made fundamental contributions to real analysis and the theory of integral equations. Lauricella, as most of his 'first-class' colleagues, preferred to publish in national or international journals, including the Rendiconti (and seldom in the AAGioenia or the BAGioenia). Instead, Fubini published five papers in the BAGioenia, two in the AAGioenia and seven in the Rendiconti during the period 1891-1908. In particular, Fubini's papers published in the BAGioenia illustrate the Lebesgue integral [Fubini, 1903] and Fredholm's formula for solving a special kind of integral equations [Fubini, 1905]. Severini published prolifically in the proceedings of the Sicilian academies, as we shall see later.

In this period, mathematics professors at the University of Catania became more and more involved in the life of the Accademia Gioenia, in which they often had institutional charges such as secretaries, librarians or simply members of the Academy's chief committee. This significantly increased the number of mathematical publications in the AAGioenia. Pennacchietti was the author of the greatest number of mathematical papers to appear in the AAGioenia between 1890 and 1908: 19 papers out of a total of 53. Pennacchietti graduated from the University of Pisa in 1874 and then became a secondary school teacher. In 1888 he was appointed professor of mechanics at the University of Catania, where he taught until he retired. His research focused on equations of particular motions and more generally on the solution of ODEs and PDEs. For his mathematical interests and methods, Pennacchietti should be considered a 19th-century mathematician, even though he mainly worked and published in the early 20th century. His work was sometimes linked to that of Vincenzo Amato, who in 1901 graduated from the University of Catania, where he was libero docente and became university professor many years later, only in 1936, after teaching at secondary schools for over thirty years. Both Pennacchietti and Amato had a local career at the University of Catania. The other authors were the geometers Pieri (2 articles), Marletta (5 papers) and their students; nevertheless, there are 5 papers published by mathematicians from Messina - Paolino Fulco (3 papers), Maggi (1) and Martinetti (1).

Several students and mathematics teachers also published in the AADafnici and the AAZelanti (see Annex 2). Their papers concern mathematics exercises or thesis excerpts. ${ }^{26}$ The other publications are research papers mainly on geometrical subjects - except for two papers published by Amato on mathematical physics [Amato, 1904-05] and [Amato, 190506].

${ }^{26}$ In the AADafnici, Alfio Fichera, a secondary school teacher, discussed mathematics exercises [Fichera 1896], and Rosario Scaccianoce, who graduated in mathematics from the University of Catania in 1905, published an excerpt of his thesis concerning the theory of surfaces [Scaccianoce, 1905]. Similarly, in the AAZelanti, Gaetano Caldarera's paper is a simple exercise on power series [Caldarera, 1893], while Natale Marseglia analysed formulae that link the coefficients and solutions of an algebraic equation [Marseglia 1907]. 
Even in Messina the level of mathematical studies improved substantially at the turn of the 20th century, when a number of non-local mathematicians were appointed professors at the university - Roberto Marcolongo (in Messina from 1895 to 1908), Giulio Vivanti (from 1895 to 1908), Gino Fano (from 1899 to 1902), Giuseppe Bagnera (from 1901 to 1908), and Tommaso Boggio (1908). Boggio and Marcolongo made remarkable contributions to mechanics and mathematical physics, while Vivanti was an analyst who held several institutional positions in the Peloritana Academy from 1897 onwards. Vivanti published 26 papers in the Rendiconti on complex analysis and the theory of differential equations, eight of them during his stay in Messina. The first note published by Poincare in the Rendiconti in 1888 [Poincaré, 1888] was inspired by a paper by Vivanti published in the same volume of the journal [Vivanti, 1888]. Apparently, there was no mathematical link between his research papers in the Rendiconti and the two papers published in the AAPeloritana addressed to nonspecialists: [Vivanti, 1904-05] explains the theory of fifth degree equations, and [Vivanti, 1908] illustrates the modern notion of "infinity". Another paper addressed to mathematics teachers or a wider audience was published in the AAPelaritana by Martinetti, who considered a problem of elementary geometry concerning tetrahedra [Martinetti, 1903-04]. Nevertheless, most articles in the AAPeloritana were research papers that focused not only on topics of algebraic geometry, but also on mathematical physics thanks to Roberto Marcolongo and his student Luciano Orlando (especially in the decade 1898-1908). One exception is the mathematics teacher Paolino Fulco from Messina, who published the first mathematical papers in the AAPeloritana [Fulco, 1898-99a], [Fulco, 1898-99b] on functional operations, following research inaugurated by Salvatore Pincherle and Vito Volterra. He continued publishing in the AAPeloritana and the AAGioenia on special functions [Fulco, 1904-05], [Fulco, 1907a], [Fulco, 1907b], when he had already left Sicily to teach in other parts of Italy. Marcolongo published eleven papers in the Rendiconti, four during the years he was professor in Messina. Most of them - written in collaboration with Cesare Burali-Forti - concern the search for an international vector notation to be presented to the International Congress of Mathematicians in Rome (1908). His 1902 paper [Marcolongo, 1902] is the well-organized summary of his two articles published in the AAPeloritana [Marcolongo, 1901-02a], [Marcolongo, 1901-02b]. Both concern the "Dirichlet problem for biharmonic functions", particularly Green's method for this generalized Dirichlet problem. ${ }^{27}$ Amato and Orlando were interested in the same research. In his article [Amato, 1904-05] Amato started out from some works by Fubini and Lauricella, and analyzed some properties of biharmonic functions for a 3-sphere. Orlando published several papers on that subject in the Rendiconti dell'Accademia dei Lincei, Giornale di Matematica and the Rendiconti. In a 1906 article in the AAPeloritana, he considered biharmonic equations and the generalized Dirichlet problem for special cases [Orlando, 1905-06]. He cited the papers by Marcolongo, Volterra, Boggio, and Hilbert, and solved the case of a parallelepiped and that of a region bounded by two

\footnotetext{
${ }^{27}$ For more details on biharmonic functions and the different solution strategies, see [Archibald and Tazzioli, 2014] and [Nastasi and Tazzioli, 2004].
} 
parallel planes. We point out that in 1907 Lauricella and Boggio were awarded the Prix Vaillant of the Paris Academy of Sciences which had proposed a vibrating membrane problem leading to biharmonic functions. ${ }^{28}$ This research was not restricted to Sicily, but it interested some 'first-class' mathematicians such as Vito Volterra, Tullio Levi-Civita, the French Jacques Hadamard, and the Pole Stanisław Zaremba.

The year 1908 marked a discontinuity in Messina's mathematical life. In fact, it was the year of the terrible earthquake that severely hit South Calabria and North-Eastern Sicily. In Messina the number of victims was estimated at about 60,000 , corresponding to $40 \%$ of the population at that time. Local institutions were seriously affected by the catastrophe and some of them were definitively destroyed. Cultural activities, including mathematics, were not completely restored until after the First World War.

In Palermo the positive trend for mathematical studies also continued thanks to the Circolo Matematico, which attracted a number of university professors as well as several secondary school teachers and students. However, the actual internationalization of the Circolo and its journal occurred after the International Congress of Mathematicians in Heidelberg (1904) and even more after the following International Congress held in Rome in $1908 .^{29}$ In the early 1890s Francesco Gerbaldi and Gabriele Torelli became professors at the University of Palermo and deeply influenced local mathematical research. Gerbaldi graduated from the University of Turin, where he became assistant to Enrico D'Ovidio, while Torelli studied at the University of Naples. Both of them spent a substantial part of their scientific careers in Palermo (Gerbaldi from 1890 to 1908, and Torelli from 1891 to 1906). Gerbaldi was a specialist of geometry and Torelli made remarkable contributions to number theory. They collaborated with Cesaro and Guccia in training a new generation of geometers in Sicily Giuseppe Bagnera, Michele Cipolla, Pasquale Calapso, and Michele De Franchis. From 1906 to 1909 Bagnera and De Franchis collaborated in research on surfaces, for which the Academy of Sciences of Paris awarded them the prestigious Prix Bordin in $1909 .^{30}$ The same year De Franchis became professor in Catania and in 1914, after Guccia's death, the director of the Circolo Matematico. De Franchis published 20 papers in the Rendiconti and was a member of the Peloritana and Gioenia academies. Cipolla, a specialist in finite group theory, taught for many years at secondary schools and then at the University of Catania. ${ }^{31} \mathrm{He}$ published nine papers in the AAGioenia and three papers in the Rendiconti, and supervised many theses, which were published in the Atti of Sicilian academies, especially in the AAGioenia and the AAZelanti.

Sometimes in the period 1891-1908, papers in the Rendiconti were the same as those already published in one of the various Atti. For instance, the author of ten papers in the Rendiconti

\footnotetext{
28 This memoir was published in Acta Mathematica in 1909 [Lauricella, 1909]. For details on the Green method in the 19th century, see [Tazzioli, 2001].

${ }^{29}$ See [Brigaglia, 2014].

30 On the Italian school of algebraic geometry with special attention to the case of Sicily, see [Brigaglia, 2001]; on the history of the Bordin Prize, see [Brigaglia, 2016]. See also [Bagnera, 1999].

31 See [Cipolla, 1997]. On Cipolla's work, see [Bartolozzi, 1997].
} 
between 1891 and 1902, published a paper on funicular curves [Pennacchietti, 1890] and another on brachistochrone motions [Pennacchietti, 1891] in AAGioenia, then reproduced them in the Rendiconti some years later [Pennacchietti, 1892a], [Pennacchietti, 1892b]. Two papers on the classical theory of elasticity appeared in the AAGioenia in 1894 [Pennacchietti, 1894a], [Pennacchietti, 1894b] and were exactly reproduced in the Rendiconti in 1895 [Pennacchietti, 1895]. Even Amato published several papers on first integrals of the equations of motion in the AAGioenia [Amato, 1901], [Amato, 1902], in the Rendiconti [Amato, 1905] and again in the AAZelanti [Amato, 1905-06]. They are all quite similar. This publication strategy confirms that the level of the Rendiconti was still relatively local at the turn of the century; it was to become increasingly international during the following period.

Thus at the beginning of the 20th century the level of mathematical studies in Sicily was generally fairly high. In fact, a number of mathematicians from Catania and Palermo won national and international awards. The Circolo Matematico contributed to improving the quality of mathematics in Sicily, building scientific links between local and foreign mathematicians, and promoting the visibility of mathematical research throughout the island. This trend also had an effect on local academies and their publications.

Our study highlights new actors (Amato and Orlando, for instance) and transversal research fields - such as the generalized Dirichlet problem that involved mathematicians from the universities of Catania and Messina, who published papers in the AAGioenia, the AAZelanti, the AAPeloritana and the Rendiconti.

Moreover, mathematical papers published in the Atti indicate a multifaceted audience. Thesis excerpts and research papers were aimed at mathematical researchers; other articles concerning for instance the solution of simple exercises or general mathematical ideas were more of interest to teachers and intellectuals more generally.

During this period, mathematicians at the same university and also at other universities on the island began to collaborate, and published papers in the Rendiconti and in the Atti relating to each other. The process of creating a Sicilian mathematical dynamic had begun.

\section{Success and decay: 1909-1920}

After the earthquake, most of the mathematicians abandoned the University of Messina: Marcolongo moved to Naples, Martinetti and Bagnera to Palermo, Boggio to Florence and then to Turin. Martinetti came back to Messina in 1913. After 1914, new mathematicians were appointed at the University of Messina. Pasquale Calapso, who graduated from the University of Palermo with Bagnera, became professor at Messina in 1914. He made remarkable contributions to differential geometry that were especially appreciated by the German Wilhelm Blaschke. A year later another geometer, Giovan Zeno Giambelli, who belonged to Segre's school of algebraic geometry in Turin, became professor at the University of Messina, where he taught from 1915 until he retired. However, these new arrivals were not 
enough to raise the level of mathematics, and indeed the period of decay continued until the 1920s.

The AAPeloritana significantly decreased the number of its publications in the period 19091920. Marletta and his student Pasquale de Pasquale, both from the University of Catania, were the authors of the only two mathematical papers on the theory of surfaces published in the AAPeloritana [Marletta, 1915c], [De Pasquale, 1917].

On the other hand, mathematics in Catania developed and reached its maximum splendor in the 1920s. Lauricella died in 1913, and Pieri and Severini left Catania in 1908 and 1914 respectively, but new professors were appointed. In 1909 Michele De Franchis and in 1910 Michele Cipolla, both from Palermo, began teaching geometry and algebra in Catania, and in 1916 Gaetano Scorza joined them as professor of analytical geometry. Scorza, who had graduated from the University of Pisa in 1899, made a strong contribution to the theory of Riemannian matrices, hypercomplex numbers and algebras. His work influenced several mathematicians in Italy and abroad.

In the years 1909-1920 more and more young people graduated in mathematics from the University of Catania, especially in geometry and algebra, supervised by Marletta, De Franchis, Cipolla, Scorza, and Giorgio Aprile. ${ }^{32}$ Marletta mainly contributed to the theory of curves and surfaces, Cremonian transformations, and geometry in hyperspaces. In the interwar period he worked more particularly on projective differential geometry. He had a significant influence at the University of Catania, where he also supervised several theses, excerpts from which appeared in the AAZelanti, the AAGioenia and the Rendiconti. ${ }^{33}$ Aprile, Marletta and his students were the authors of six of the eleven articles which appeared in the AAZelanti in the period 1880-1920, five of them between 1908 and $1920 .^{34}$

We would point out that 56 papers appeared in the AAGioenia between 1909 and 1920. They concern not only geometry and algebra, but also analysis and mathematical physics. Severini was the most prolific of these authors with 14 papers, most of which dealt with real analysis, PDEs, and integral equations. In particular, Severini proved "Egorov's theorem", which establishes a condition for the uniform convergence of a pointwise convergent sequence of measurable functions, in a paper published in the AAGioenia [Severini, 1910] before Egorov's note [Egorov, 1911]. However, the international audience attributed the theorem to

\footnotetext{
${ }^{32}$ Aprile was a secondary school teacher who also taught at the university. He was a geometer and collaborated with Marletta and Cipolla.

33 See [Giampaglia, 1904], [D’Amico, 1905], [Ragonesi, 1915], [Grimaldi, 1917-18] [Grimaldi, 1918], [Bartolo, 1919], [Cataliotti, 1919]. We also mention the work by Giuseppina Carbonaro, who studied at the University of Catania from 1918 to 1923 and published an excerpt of her thesis entitled "Sopra una classe

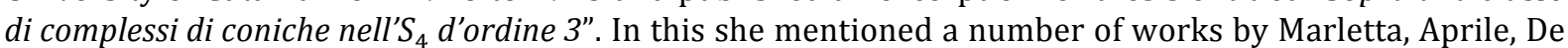
Pasquale, published in the AAGioenia [Carbonaro, 1922-26]. Carbonaro's contribution to algebraic geometry has recently been re-assessed, see [Russo, 2016].

34 Volume 10 of the AAZelanti, published in 1918, contains four papers on algebraic geometry - [Marletta, 1917-18a], [Marletta, 1917-18b], [Grimaldi, 1917-18], [Aprile, 1918]. Aprile and Marletta also published four and seven papers respectively in the AAGioenia.
} 
Egorov, apparently because his result appeared in the Comptes Rendus of the Paris Academy while Severini had published his paper in an obscure journal, as the AAGioenia was.

The other papers by Severini explored orthogonal functions and their properties. In 1913 he published a remarkable article in the Rendiconti [Severini, 1913], which summarized the results obtained in his previous seven papers published in the AAGioenia between 1910 and 1913. These papers show the different stages of his mathematical ideas before attaining the main results published in the Rendiconti. Here Severini referred to the work by David Hilbert and his students Erhard Schmidt and Friedrich Riesz, and especially to the results obtained by Lauricella. The latter, indeed, preferred to publish his research in the Rendiconti dell'Accademia dei Lincei and Rendiconti, where he cited Severini's papers in the AAGioenia. ${ }^{35}$

A number of significant changes took place at the University of Palermo between 1909 and 1920. Bagnera, who had taught in Messina, replaced Gerbaldi in 1908. Two professors moved from Catania to Palermo: Scorza in 1909 and De Franchis in 1914. Algebraic geometry was then a subject of excellence in Palermo, where Bagnera and De Franchis had won the Prix Bordin in 1909.

The Circolo Matematico was increasingly becoming truly international, as was its journal. In 1909 there was an actual change in the editorial board of the Rendiconti: foreign members outnumbered Italians (26 to 14), with only two Sicilians, De Franchis and Bagnera, in addition to Guccia, the editor-in-chief). ${ }^{36}$ The number of articles by foreign authors increased considerably. Some foreign authors who published in the Rendiconti are: Paul Appell, Wilhelm Blaschke, Constantin Carathéodory, Edmund Landau, Émile Picard, and Hermann Weyl. Among the Italians, most were representatives of the celebrated school of algebraic geometry, including Guido Castelnuovo, Federigo Enriques, Francesco Severi, Gino Fano, and of course the Sicilian De Franchis (eight papers, including one in collaboration with Bagnera). ${ }^{37}$

However, the outbreak of the First World War $^{38}$ and Guccia's death in 1914 halted this positive trend. De Franchis replaced Guccia at the head of the Circolo. Nevertheless, although he shared Guccia's ideas on internationalism, he lacked the personal financial support and strong personal relationships with foreign mathematicians that Guccia had had. During the war period, Sicilian authors increased the number of their papers in the Rendiconti; in fact, they replaced their foreign colleagues who were unable to publish in the Rendiconti because of the war. In detail, seven German and Austrian papers appeared in 1914, only two in 1915, and none at all in 1916 and 1919. Italy entered the war in 1915, and the Rendiconti stopped publication in 1917 and 1918. Soon after the war, when ostracism was the official policy of

\footnotetext{
${ }^{35}$ See in particular Lauricella's paper on orthogonal functions published in the Rendiconti [Lauricella, 1910]. On Lauricella's work, see [Archibald and Tazzioli, 2014].

${ }^{36}$ See [Brigaglia, 2014].

37 The Sicilian mathematicians who published in the Rendiconti in the period 1909-1920 included Marletta (8 papers), Cipolla ( 3 papers), and Daniele ( 2 papers).

${ }^{38}$ In her paper Gispert also mentions the effects of WWI on mathematical journals publishing.
} 
the victorious countries, the Rendiconti published two papers by German mathematicians one by Alfred Baruch later "Barneck" [Baruch, 1920] and the other by Edmund Landau in collaboration with Arnold Walfisz, a Polish mathematician who had studied in Germany and was one of Landau's students [Landau and Walfisz, 1920]. Thus, very quickly the Rendiconti began again to publish works by German and Austrian authors. ${ }^{39}$ Nevertheless, at the end of 1920s the Circolo Matematico began to decline, and the Rendiconti with it.

To conclude, mathematical studies in the three main centers during this period were rather uneven, and that had an impact on Sicilian journals. The terrible earthquake of 1908 affected culture and institutions in Messina, including mathematical activity and publications in the AAPeloritana, while the First World War had a major impact on the Rendiconti because of the substantial presence of foreign authors (see Annex 3). We point out that the First World War had no visible effect on the positive trend at the University of Catania, where mathematical studies, and especially geometry and functional analysis, continued to develop. However, several students from Messina matriculated in Catania or Palermo after the 1908 earthquake. During these years there is clearly a Sicilian dynamic: several professors moved from one Sicilian university to another (especially from Messina and Palermo, but also between Catania and Palermo) (see Annex 1); the authors of mathematical articles in the Atti came from all three Sicilian universities, and some of them published a large number of papers in the Rendiconti as well (see Annex 2). There were also more and more young people graduating from Sicilian universities who went on to become authors of articles in the Atti or the Rendiconti, including Orlando (Messina), Marletta (Catania), De Franchis (student in Palermo and then professor in Catania and finally in Palermo), and Cipolla (student in Palermo and then teacher at the University of Catania).

\section{Concluding remarks}

\subsection{The interplay between the Atti and the Rendiconti}

Mathematicians who published in the Atti of the Sicilian academies included 19 university professors and 27 mathematics teachers, seven of whom also taught at the university (see Annexes 1 and 2). Therefore, in the period 1880-1920, a significant number of teachers did mathematical research and published in the Atti and the Rendiconti - in the Rendiconti particularly before the turn of the century before the journal had become truly international. This shows a collaboration between university professors and secondary school teachers.

We point out that university professors generally published in the proceedings of the Sicilian academies only during the time they lived in Sicily, when they were probably asked to publish in these local journals. Once they left Sicily, they generally stopped publishing in the Atti and went on to write papers for the Rendiconti.

\footnotetext{
${ }^{39}$ In the 1920s many foreign mathematicians published in the Rendiconti. Most were from Germany, the USA and Great Britain, but there were also some from France, eastern European countries, and Russia.
} 
Some of the authors had "local careers", which did not always imply a less important career. De Franchis, for instance, graduated from the University of Palermo and spent just four years (1905-1909) outside Sicily in his entire scientific career; Lauricella was professor in Catania from 1898 until his death in 1913, except for the academic year 1910-11 when he was at the University of Rome. Both received international awards and were reputed abroad as highlevel mathematicians. The case of Pennacchietti is different: he had a local career at the University of Catania and his work was almost unknown outside Sicily. Naturally this also reflected on their publications: while Pennacchietti published in the Rendiconti only before it became a truly international journal, Lauricella and De Franchis mostly published in the Rendiconti and very seldom in the Atti.

\subsection{A Sicilian dynamic}

Analysis of the not inconsiderable quantity of mathematics published in the Atti allows us to shed light on mathematics in Sicilian institutions and journals, discover authors never considered before, highlight collaboration among mathematicians, and detect transversal research subjects in Sicily. In particular, algebraic geometry, to which Bagnera, De Franchis, Marletta, Pieri and others contributed, functional analysis with the works by Severini, Lauricella, Vivanti and Fubini, and mathematical physics, which were the main topics for Marcolongo, Orlando and Lauricella, were the three main research fields in Sicily at that time. All these mathematicians published various contributions in the Atti and the Rendiconti; generally, intermediate results were published in the Atti, while more important achievements were published in the Rendiconti.

We remark that De Franchis, Bagnera, Pieri, Marletta, Scorza and others, who belonged to the three Sicilian universities, were members of the celebrated Italian school of algebraic geometry. ${ }^{40}$ Well-known mathematicians such as De Franchis and Bagnera and their influence in Palermo and Catania certainly contributed to making algebraic geometry an important discipline in Sicily. During his stay in Catania from 1909 to 1914, De Franchis most likely influenced his colleagues, and Marletta in particular. It would therefore be fair to ask whether Marletta was a member of this school or not. If we consider all his work, including his articles in the AAGioenia that are a non-negligible part of his scientific production, the answer is affirmative. $^{41}$

Finally, our research highlights that several Sicilian mathematicians, who were also authors of numerous articles published in the Atti and the Rendiconti, were well reputed in Italy and abroad. Many of them (Bagnera, Boggio, De Franchis, Lauricella, Marcolongo, Orlando, Severini) participated in the International Congress of Mathematicians in Rome in 1908. They lectured on several topics - biharmonic equations, the theory of integral equations, analytic

\footnotetext{
40 On the subject see [Brigaglia and Ciliberto, 1995], [Ciliberto and Sernesi, 1991].

41 See the presentation of Marletta's scientific work and his list of publications by Renato Calapso [Calapso, 1943-49]. Marletta published several papers in the AAG, in particular on Cremonian transformations and the geometry of hyperspaces.
} 
functions, vector notation, elasticity and geometry - linked to the most recent developments in international mathematical research.

\subsection{Mathematics in Catania in the 1920s}

The rich mathematical background at the turn of the 20th century that emerges from this study helps explain the exceptional development of mathematics at the University of Catania in the 1920s, when Catania became one of the most important Italian centers for abstract algebra in Italy (together with Pisa). ${ }^{42}$ In 1921 a new mathematical society was founded in Catania, the Circolo Matematico di Catania, with the aim of developing even stronger links between mathematics teachers, students and the university. The Circolo in Catania supported two new mathematical journals, Esercitazioni Matematiche and Note e Memorie, directed at teachers and students. The Circolo gave university student awards, organized mathematics lectures for a non-specialist audience, and started the Seminario Matematico, a series of lectures on mathematical subjects, often given by local professors and directed at mathematics teachers. University professors and mathematics teachers in Catania were involved in the Circolo Matematico: Gaetano Scorza and Michele Cipolla were the editors-in-chief of Note $e$ Memorie and Esercitazioni Matematiche respectively; Marletta, Sebastiano Catania, Aprile, Amato, and others contributed to the journals or gave lectures for the Circolo. ${ }^{43} \mathrm{We}$ also mention the significant presence of women involved in the Circolo's activities and in university teaching during $1920 \mathrm{~s}$ and $1930 \mathrm{~s}^{44}$

To conclude, mathematical papers in the Atti of the Sicilian academies and their interplay with publication in the Rendiconti clearly show significant mathematical activity in Sicily in the period 1880-1920. A Sicilian dynamic emerges, where mathematicians often moved from one Sicilian university to another, collaborated, contributed to common areas of research, were involved in local academies, and published in the various Atti as well as in the Rendiconti. This dynamic also helps explain the extraordinary development of mathematics in Catania during the 1920 s.

\footnotetext{
42 In this respect we mention Giuseppe Fichera's thesis supervised by Scorza and published in the AAGioenia [Fichera, 1922], and the works published by Nicolò Spampinato, who graduated in 1919, in the AAGioenia in the 1920s; on the Catanian school in the 1920s, see [Russo, 2016].

43 The Circolo Matematico of Catania was indeed founded with the aim of promoting mathematical studies in Catania through secondary school teachers and university students. On the Circolo and its mathematical journals, see [Tazzioli, 1999], [Scimone, 1989], [Micale, 1992].

${ }^{44}$ We mention Pia Nalli, full professor of calculus at the University of Catania since 1927 onwards, Giuseppina Carbonaro, Angela Zelarovich, Maria Precchia, Matilde Prampolini, and Laura Baeri. See the Archivio Storico of the University of Catania. On the history of female mathematicians at the University of Catania in the twentieth century, and especially on Pia Nalli, see [Branciforte and Tazzioli, 2002].
} 


\section{References $^{45}$}

Alberghina, M. (Ed.), 2005. L'Accademia Gioenia. 180 anni di cultura scientifica (18242004). Maimone Editore, Catania.

Amato, V.,1901. Sugl'integrali delle equazioni del moto di un punto materiale. Nota I. AAGioenia (4), 14, 14 pp.

Amato, V., 1902. Sugl'integrali delle equazioni del moto di un punto materiale. Nota II. AAGioenia (4), 17, 10 pp.

Amato, V., 1904-05. Sull'estensione alla superficie sferica di talune proposizioni fondamentali relative alle equazioni della fisica matematica. AAZelanti (3), 3, 15-30. Amato, V., 1905. Sul sistema di due integrali primi comuni ad una classe di problemi, Rendiconti 19, 1905, 57-61.

Amato, V., 1905-06. Sugl'integrali primi comuni a più problemi del moto d'un sistema. AAZelanti (3), 4, 15-20.

Aprile, G., 1918. Di alcune congruenze d'ordine due di superficie nell' $S_{4}$ e di coniche nell' $S_{3}$. AAZelanti (3), 10, 34 pp.

Archibald, T. and Tazzioli, R., 2014. Integral equations between theory and practice: the cases of Italy and France to 1920. Archive for History of Exact Sciences 68, 547-597.

Bagnera, G., 1999. Opere (ed. by G. Zappa and G. Zacher). Supplemento ai Rendiconti del Circolo Matematico di Palermo, s. 2, vol. 60.

Bartolo, M., 1919. Delle superficie razionali d'ordine $\mathrm{n}=8$, con infinite coniche, i cui piani non costituiscono un fascio. AAGioenia (5), 12, 13 pp.

Bartolozzi, F., 1997. L'opera matematica di Michele Cipolla con particolare riguardo alla Teoria dei Gruppi. In: Scimone, A. and Spagnolo, F. (Eds.), Michele Cipolla (1880-1947). La figura e l'opera. Atti del convegno celebrativo in occasione del cinquantenario della morte. Associazione degli Insegnanti e dei Cultori di Matematica, Palermo, 13-22.

Baruch, A., 1920. Ueber vierfach hyperboloide Tetraeder. Rendiconti 44, 261-300.

Biffignandi, A., 1890. Le principali proprietà delle grandezze proporzionali, nuovamente esposte. AAZelanti 2, 62-84.

Bottazzini, U. and Dahan-Dalmedico, A. (Eds.) 2001. Changing Images in Mathematics. From the French Revolution to the New Millenium. Routledge, London.

Branciforte, L. and Tazzioli, R., 2002. La presenza delle donne nella matematica e nel suo insegnament. In: Dollo, C. (Ed.), Per un bilancio di fine secolo. Catania nel Novecento. Società di Storia Patria per la Sicilia Orientale, Catania, 2002, pp. 95-112.

\footnotetext{
45 We denote, as in the paper:

Rendiconti $=$ Rendiconti del Circolo Matematico di Palermo

AADafnici = Atti dell'Accademia dei Dafnici di Acireale

AAZelanti = Atti e rendiconti dell'Accademia di scienza, lettere e arti dei Zelanti e PP. dello studio di Acireale

BAGioenia = Bollettino delle Sedute dell'Accademia Gioenia di scienze naturali

AAGioenia = Atti dell'Accademia Gioenia di scienze naturali

AAPeloritana = Atti dell'Accademia Peloritana dei Pericolanti
} 
Brigaglia, A., 2001. The creation and the persistence of national schools: The case of Italian algebraic geometry. In: [Bottazzini and Dahan-Dalmedico 2001], pp. 187-206.

Brigaglia, A., 2014. The Annali di Matematica and the Rendiconti del Circolo Matematico di Palermo: Two Different Steps in the Dissemination and Progress of Mathematics in Italy.In: [Gerini and Verdier, 2014], pp. 155-178.

Brigaglia, A., 2016. Picard and the Italian Mathematicians: The History of the Three Prix Bordin. In: Brechenmacher, F., Jouve, G., Mazliak, L., and Tazzioli, R. (Eds.), Images of Italian Mathematics in France. The Latin Sisters, from Risorgimento to Fascism. Birkhäuser, Basel, pp. 93-126.

Brigaglia, A. and Ciliberto, C., 1995. Italian Algebraic Geometry Between the Two World Wars. Queen's Papers in Pure and Applied Mathematics 100, 223 pp.

Brigaglia, A. and Masotto, G., 1982. Il Circolo Matematico di Palermo, Dedalo, Bari.

Calapso, R., 1943-49. Giuseppe Marletta. AAGioenia (6), 6, 1-24.

Caldarera, G., 1893. Potenza di una serie particolare. AAZelanti, 5, 8 pp.

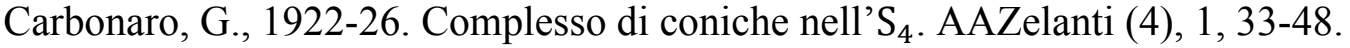

Catania, S., 1906. Corso di algebra elementare ad uso delle scuole secondarie superiori. Giannotta, Catania.

Catania, S., 1908. Elementi di aritmetica ed algebra per le scuole secondarie inferiori. Giannotta, Catania.

Ciliberto, C. and Sernesi, E., 1991. Some aspects of the scientific activity of Michele De Franchis. In: De Franchis, M., Opere, Supplemento ai Rendiconti del Circolo Matematico di Palermo (2), 27, 1991, pp. 3-36.

Cipolla, M., 1997. Opere (ed. by G. Zappa and G. Zacher), Supplemento ai Rendiconti del Circolo Matematico di Palermo (2), 47.

Cosentini, C., 1970. Trecento anni dalla fondazione dell'Accademia degli Zelanti (16711971). Memorie e Rendiconti dell'Accademia degli Zelanti (1), 10, p. 7-14.

D’Amico, F., 1905. Sulla varietà quartica con tre piani semplici dello spazio a quattro dimensioni. AAGioenia (4), 18, 17 pp.

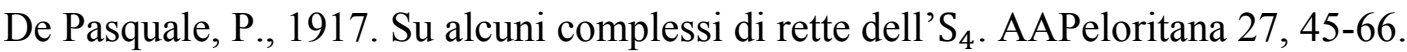

Donato, M., 2003. Presidenti e segretari generali dell'Accademia di scienze, lettere e belle arti degli Zelanti e dei Dafnici dalle origini al 2004. Memorie e Rendiconti dell'Accademia degli Zelanti (5), 2, 23-30.

Egorov, D., 1911. Sur les suites de fonctions mesurables. Comptes Rendus hebdomadaires de l'Académie des Sciences de Paris 152, 244-246.

Faifofer, A., 1878. Elementi di algebra e di trigonometria. Tip. emiliana, Venezia, 1878. Fichera, A., 1896. Analisi geometrica a due coordinate, soluzione ed esercizi proposti da G. Salmon. AADafnici 4, 39-83.

Fubini, G. 1903. Sugli integrali definiti di una funzione finite. Bollettino delle sedute della Accademia Gioenia 80, 19-23.

Fubini, G., 1905. Sopra una formula di Fredholm nel problema dell'inversione degli integrali definiti. BAGioenia 83, 3-7. 
Fulco, P., 1898-99a. Alcune proprietà delle operazioni funzionali distributive. AAPeloritana 13, 189-217.

Fulco, P., 1898-99b. Sui gruppi e sugli insiemi di operazioni funzionali distributive ad unica determinazione. AAPeloritana 13, 495-535.

Fulco, P., 1904-05. Le funzioni X(z). AAPeloritana 19, 33-56.

Fulco, P., 1907a. Proprietà delle funzioni speciali per un'operazione in relazione alle sue derivate funzionali. AAPeloritana 22, 243-282.

Fulco, P., 1907b. I coefficienti delle equazioni differenziali lineari, omogenee di secondo ordine, ammettenti fra i loro integrali particolari funzioni g(z). AAGioenia (4), 20.

Giacardi, L. (Ed.) 2006. Da Casati a Gentile. Momenti di storia dell'insegnamento secondario della matematica in Italia. Lumières Internationales, Lugano.

Giampaglia, N., 1904. Formole d'incidenza per le coppie « punto e retta, retta e piano, punto e piano » nello spazio ad n dimensioni. AAGioenia (4), 17, $28 \mathrm{pp}$.

Grimaldi, G., 1917. Delle superficie algebriche d'ordine 7, con un fascio ellittico di coniche. Rendiconti 42, 80-84.

Grimaldi, G., 1917-18. Di alcune congruenze di $C^{5}$ e $C^{6}$ dell' $S_{3}$. AAZelanti (3), 10, 7 pp. Grimaldi, G.1918. Delle congruenze di rette generate da infinite coniche-inviluppo.

AAGioenia (5), 11, 20 pp.

Landau, E. and Walfisz, A., 1920. Über die Nichtfortsetzbarkeit einiger durch DirichletscheReihen definierter Funktionen. Rendiconti 44, 82-86.

Lauricella, G., 1909. Sur l'intégration de l'équation relative à l'équilibre des plaques élastiques encastrées. Acta Mathematica 32, 201-256.

Lauricella, G., 1910. Sopra gli sviluppi in serie di funzioni ortogonali. Rendiconti (5), 29, I, 153-163.

Marchisotto, E. A. and Smith, J., 2007. The Legacy of Mario Pieri in Geometry and Arithmetic. Birkhäuser, Basel, 2007.

Marcolongo, R., 1901. Determinazione di Green di grado n, nel caso della sfera. Rendiconti della R. Accademia dei Lincei (5), 10, II,131-137.

Marcolongo, R., 1901-02a. Sulla teoria delle funzioni sferiche. AAPeloritana 19, 109-126. Marcolongo, R., 1901-02b. Risoluzione del problema di Dirichlet per un solido limitato da due cilindri circolari retti coassiali e da due piani passanti per l'asse. AAPeloritana 19, 127142.

Marcolongo, R., 1902. Sulla funzione di Green di grado n per la sfera. Rendiconti 16, 230235.

Marcolongo, R., 1921. Relatività. Principato, Messina.

Marletta, G., 1915a. Sulle superficie algebriche con infinite coniche, e in particolare, su quelle d'ordine 5. AAGioenia (5), 8, $21 \mathrm{pp.}$

Marletta, G., 1915b. Delle superficie algebriche d'ordine 6 con infinite coniche. Rendiconti 40, 217-232.

Marletta, G., 1915c. Le superficie algebriche d'ordine 6 con infinite coniche. AAPeloritana $27,15 \mathrm{pp}$. 
Marletta, G., 1917-18a. Rappresentazione di certe forme dell' $S_{4}$ nelle coppie di un'involuzione dell' $\mathrm{S}_{3}$. AAZelanti (3), 10, $2 \mathrm{pp}$.

Marletta, G., 1917-18b. Un'involuzione cremoniana piana nuova anche per i valori 2, 3, 4, 5 della classe. AAZelanti (3), 10, 3 pp.

Marseglia, N., 1907. Sulle relazioni fondamentali tra i coefficienti e le radici di una equazione algebrica di grado qualunque. AAZelanti (3), 5, 6 pp.

Martinetti, V., 1903-04. Sulle coppie di tetraedri reciprocamente inscritti e circoscritti.

AAPeloritana 18, 136-144.

Micale, B., 1992. Esercitazioni matematiche. Una rivista ad uso degli studenti universitari.

L'insegnamento della matematica e delle scienze integrate 15, 575-587.

Morale, M., 1899. Involuzione di grado $\mathrm{n}$ e specie 1 in uno spazio a n-1 dimensioni.

Rendiconti 13, 274-284.

Nastasi, P. and Tazzioli, R., 2004. Sulla determinazione della m.ma funzione di Green e questioni connesse. Supplemento ai Rendiconti del Circolo Matematico di Palermo. Studies in the History of Modern Mathematics (2), Suppl. 72, 71-101.

Novarese, D. (Ed.), 2011. Accademie e Scuole. Istituzioni, luoghi, personaggi, immagini della cultura e del potere. Giuffré Editore, Messina.

Occhipinti, R., Linee isocline rispetto alle bisettrici delle linee di curvature. Rendiconti 36, 29-34.

Oliva, G., 1916. Memorie storiche e letterarie della Reale Accademia Peloritana di Messina dal tempo della sua fondazione fino al presente. AAPeloritana 27, 95-387.

Orlando, L., 1905-06. Sopra alcuni problemi di Fisica matematica. AAPeloritana 20, II, pp. 151.

Pennacchietti, G., 1890. Sulle curve funicolari. AAGioenia (4), 3, 271-283.

Pennacchietti, G., 1891. Sul moto brachistocrono d'un sistema qualunque di punti materiali.

AAGioenia (4), 4, 12 pp.

Pennacchietti, G., 1892a. Sulle curve funicolari. Rendiconti 6, 14-25.

Pennacchietti, G., 1892b. Sul moto brachistocrono d'un sistema qualunque di punti materiali.

Rendiconti 6, 52-62.

Pennacchietti, G., 1894a. Sulle equazioni di equilibrio delle superficie flessibili e insestensibili. AAGioenia (4), 8, 1894, 11 pp.

Pennacchietti, G., 1894b. Sull'integrazione dell'equazioni di equilibrio delle superficie flessibili e insestensibili. AAGioenia (4), 8, 1894, 4 pp.

Pennacchietti, G., 1895. Sull'equilibrio delle superficie flessibili e insestensibili. Rendiconti 9, 87-95.

Poincaré, H., 1888. Sur une propriété des fonctions analytiques. Rendiconti 2, 197-200.

Ragonesi, S., 1915. Delle superficie razionali d'ordine 9 con infinite coniche. AADafnici (2), 4, $22 \mathrm{pp}$.

Reeve, M.D., 1982. Longus, Daphnis and Chloe. Leipzig, Teubner.

Russo, F., 2016. On the Geometry of Some Special Projective Varieties.

Cham/Heidelberg/New York/ Dordrecht/London, Springer. 
Scaccianoce, R., 1905. Sopra una superficie del $7^{\circ}$ ordine generabile con quattro piani proiettivi. AADafnici (2), 1, $28 \mathrm{pp}$.

Scimone, A., 1989. Il Circolo matematico di Catania. Bollettino di storia delle scienze matematiche 9, 171-191.

Severini, C., 1910. Sulla successione di funzioni ortogonali. AAGioenia (5), 3, 10 pp.

Severini, C., 1913. Sulla teoria di chiusura dei sistemi di funzioni ortogonali. Rendiconti 36, 177-202.

Tazzioli, R., 1999. La matematica all’Università di Catania dall'Unità alla riforma Gentile. Annali di storia delle università italiane 3, 207-224.

Tazzioli, R., 2001. Green's function in some contributions of 19th century mathematicians. Historia Mathematica 28, 232-252.

Tazzioli, R., 2005. I matematici e l'Accademia Gioenia. In: [Alberghina, 2005], pp. 178-183. Vivanti, G., 1888. Sulle funzioni a infiniti valori. Rendiconti 2, 135-138.

Vivanti, G., 1904-05. Cenni sulla teoria delle equazioni di quinto grado. AAPeloritana 19, I, 104-133.

Vivanti, G., 1908. La nozione dell'infinito secondo gli studi più recenti. AAPeloritana 23, 155. 


\section{Annex 1}

University professors in Sicily from 1880-1920 (plain text). Assistant professors ("liberi docenti") and secondary school teachers (in bold), who published in the Atti of the Sicilian academies.

\begin{tabular}{|c|c|c|c|c|}
\hline Name & Subject & $\begin{array}{l}\text { University of } \\
\text { Catania }\end{array}$ & $\begin{array}{l}\text { University of } \\
\text { Messina }\end{array}$ & $\begin{array}{l}\text { University of } \\
\text { Palermo }\end{array}$ \\
\hline Albeggiani Giuseppe & Calculus & & & $1880-1892 \mathrm{Pr}$ \\
\hline Caldarera Francesco & Mechanics & & & $\begin{array}{l}\text { Student } \\
1880-1900 \mathrm{Pr}\end{array}$ \\
\hline Pincherle Salvatore & Calculus & & & 1880-1881 Pr \\
\hline Capelli Alfredo & Algebra & & & 1881-1886 Pr \\
\hline Mollame Vincenzo & $\begin{array}{l}\text { Algebra, } \\
\text { Geometry }\end{array}$ & 1882-1911 Pr & & \\
\hline Distefano Mario & Geometry & Up to $1885 \mathrm{Pr}$ & & \\
\hline Maddem Lorenzo & Mechanics & Up to $1885 \mathrm{Pr}$ & & \\
\hline Catania Sebastiano & Geometry & $\begin{array}{l}\text { Student } \\
1885-1915 \text { AP }\end{array}$ & & \\
\hline Cesaro Ernesto & Algebra & & & $1886-1891$ \\
\hline Maisano Giovanni & $\begin{array}{l}\text { Algebra, } \\
\text { Geometry }\end{array}$ & & 1886-1897 Pr & Student \\
\hline Chizzoni Francesco & Geometry & 1886-1899 Pr & & \\
\hline Maggi Gian Antonio & Calculus & & 1886-1895 Pr & \\
\hline Martinetti Vittorio & Geometry & & $\begin{array}{l}\text { 1886-1909 Pr } \\
\text { From } 1913\end{array}$ & 1909-1913 \\
\hline Pennacchietti Giovanni & $\begin{array}{l}\text { Mechanics, } \\
\text { Mathematical } \\
\text { physics }\end{array}$ & 1888-1916 Pr & & \\
\hline Guccia Giovan Battista & Geometry & & & 1889-1914 Pr \\
\hline Gerbaldi Francesco & $\begin{array}{l}\text { Algebra, } \\
\text { Geometry }\end{array}$ & & & $1890-1908 \mathrm{Pr}$ \\
\hline Torelli Gabriele & Algebra & & & $1891-1906 \mathrm{Pr}$ \\
\hline Caldarera Gaetano & Geometry & $\begin{array}{l}\text { Student } \\
1892-1906 \text { AP }\end{array}$ & & \\
\hline Vivanti Giulio & Calculus & & 1895-1908 Pr & \\
\hline Marcolongo Roberto & Mechanics, & & 1895-1908 Pr & \\
\hline
\end{tabular}




\begin{tabular}{|c|c|c|c|c|}
\hline & $\begin{array}{l}\text { Mathematical } \\
\text { physics }\end{array}$ & & & \\
\hline Fano Gino & Geometry & & 1899-1902 Pr & \\
\hline Lauricella Giuseppe & Calculus & $\begin{array}{l}1898-1910 \mathrm{Pr} \\
19111913 \mathrm{Pr}\end{array}$ & & \\
\hline Pieri Mario & Geometry & 1899-1908 Pr & & \\
\hline Bagnera Giuseppe & $\begin{array}{l}\text { Algebra, } \\
\text { Geometry }\end{array}$ & & 1901-1908 Pr & $\begin{array}{l}\text { Student } \\
1895-1901 \mathrm{AP} \\
\text { From } 1908 \mathrm{Pr}\end{array}$ \\
\hline Amato Vincenzo & & $\begin{array}{l}\text { Student } \\
\text { From } 1901 \mathrm{AP}\end{array}$ & & \\
\hline Marletta Giuseppe & Geometry & $\begin{array}{l}\text { Student } \\
\text { From } 1902 \mathrm{AP}\end{array}$ & & \\
\hline Fubini Guido & Calculus & $1902-1905 \mathrm{Pr}$ & & \\
\hline Orlando Luciano & Mechanics & & 1903-1908 AP & \\
\hline Severini Carlo & $\begin{array}{l}\text { Calculus } \\
\text { Mathematical } \\
\text { physics }\end{array}$ & 1905-1914 Pr & & \\
\hline Gebbia Michele & $\begin{array}{l}\text { Mathematical } \\
\text { physics }\end{array}$ & & & $\begin{array}{l}\text { Student } \\
1907-1914 \mathrm{AP} \\
\text { From } 1914 \mathrm{Pr}\end{array}$ \\
\hline Boggio Tommaso & $\begin{array}{l}\text { Mathematical } \\
\text { physics }\end{array}$ & & $1908 \mathrm{Pr}$ & \\
\hline Burgatti Pietro & Mechanics & & 1908-1909 Pr & \\
\hline De Franchis Michele & Geometry & 1909-1914 Pr & & $\begin{array}{l}\text { Student } \\
\text { From 1914 Pr }\end{array}$ \\
\hline Cipolla Michele & Calculus & From $1910 \mathrm{AP}$ & & $\begin{array}{l}\text { Student } \\
\text { Prof. in } 1923\end{array}$ \\
\hline Aprile Giorgio & Geometry & From $1912 \mathrm{AP}$ & & \\
\hline Daniele Ermenegildo & $\begin{array}{l}\text { Mathematical } \\
\text { physics }\end{array}$ & From $1913 \mathrm{Pr}$ & & \\
\hline Calapso Pasquale & Geometry & & From $1914 \mathrm{Pr}$ & Student \\
\hline Laura Ernesto & $\begin{array}{l}\text { Mathematical } \\
\text { physics }\end{array}$ & & 1915-1916 Pr & \\
\hline Giambelli Giovan Zeno & Geometry & & From $1915 \mathrm{Pr}$ & \\
\hline Scorza Gaetano & Geometry & From $1916 \mathrm{Pr}$ & & $1909-1912 \mathrm{AP}$ \\
\hline Bottasso Matteo & $\begin{array}{l}\text { Mathematical } \\
\text { Physics }\end{array}$ & & 1916-1918 Pr & \\
\hline
\end{tabular}




\begin{tabular}{|l|l|l|l|l|}
\hline Signorini Antonio & $\begin{array}{l}\text { Mathematical } \\
\text { physics }\end{array}$ & & & From 1916 Pr \\
\hline Picone Mauro & Calculus & From 1919 Pr & & \\
\hline
\end{tabular}

AP $=$ Assistant Professor $; \mathrm{Pr}=$ Professor 


\section{Annex 2}

All the authors of mathematical papers in the Atti of the Sicilian academies in the period 1880-1920. University professors (plain text); mathematics teachers, assistant professors, and students (in bold). We report the number of their papers in the Atti, the Rendiconti del Circolo Matematico di Palermo and "other journals", and their research field. Here there are three women: Rosaria Abbia (born in 1889 in Palermo) graduated from the University of Palermo in 1912; Gelsomina Grimaldi (born in 1894 in Messina) graduated from the University of Catania in 1918; Maria Precchia (born in 1893 in Messina) graduated from the University of Catania in 1915. They all became secondary school teachers, see https://cirmath.hypotheses.org/les-outils-de-cirmath/materiaux-supplementaires-pour-le-volumeinterplay-between-journals-at-various-scales-historia-mathematica-2018

\begin{tabular}{|c|c|c|c|c|c|c|c|c|}
\hline Name & AAD & AAZ & BAG & AAG & AAP & RCMP & Others & Subject \\
\hline Abbia R. & 0 & 0 & 0 & 1 & 0 & 0 & 1 & Geometry \\
\hline Amato V. & 0 & 2 & 0 & 5 & 0 & 2 & 9 & Geometry, Analysis \\
\hline Aprile G. & 0 & 2 & 0 & 5 & 0 & 0 & 4 & Geometry \\
\hline Bartolo M. & 0 & 0 & 0 & 1 & 0 & 0 & 0 & Geometry \\
\hline Biffignandi A. & 0 & 1 & 0 & 0 & 0 & 0 & 2 & Elementary mathematics \\
\hline Cafiero D. & 0 & 0 & 0 & 0 & 1 & 0 & 0 & Mathematical physics \\
\hline Caldarera F. & 0 & 0 & 0 & 2 & 0 & 4 & 5 & Mechanics \\
\hline Caldarera G. & 0 & 2 & 0 & 3 & 0 & 0 & 1 & Geometry, Analysis \\
\hline Carrone C. & 0 & 0 & 0 & 1 & 0 & 1 & 1 & Geometry \\
\hline Cataliotti A. & 0 & 0 & 0 & 1 & 0 & 0 & 0 & Geometry \\
\hline Catania S. & 0 & 0 & 0 & 1 & 0 & 0 & 26 & Elementary mathematics \\
\hline Chizzoni F. & 0 & 0 & 0 & 1 & 0 & 0 & 4 & Geometry \\
\hline Cipolla M. & 0 & 0 & 0 & 9 & 0 & 3 & 32 & Geometry \\
\hline D'Amico F. & 0 & 0 & 0 & 1 & 0 & 0 & 0 & Geometry \\
\hline Daniele E. & 0 & 0 & 0 & 3 & 0 & 3 & 33 & Mathematical physics \\
\hline De Franchis M. & 0 & 0 & 0 & 1 & 0 & 20 & 7 & Geometry \\
\hline De Pasquale $P$. & 0 & 0 & 0 & 0 & 1 & 0 & 0 & Geometry \\
\hline Fano G. & 0 & 0 & 0 & 0 & 1 & 7 & $>50$ & Geometry \\
\hline Fichera A. & 1 & 0 & 0 & 0 & 0 & 0 & 0 & Geometry \\
\hline Fubini G. & 0 & 0 & 5 & 3 & 0 & 9 & $>50$ & Analysis \\
\hline Fulco P. & 0 & 0 & 0 & 3 & 4 & 0 & 0 & Analysis \\
\hline Garbieri G. & 0 & 0 & 0 & 1 & 0 & 0 & 11 & Geometry \\
\hline Giampaglia N. & 0 & 0 & 0 & 1 & 0 & 0 & 0 & Geometry \\
\hline Grimaldi G. & 0 & 1 & 0 & 1 & 0 & 1 & 1 & Geometry \\
\hline Lauricella G. & 0 & 0 & 0 & 2 & 0 & 3 & $>50$ & Mathematical physics, analysis \\
\hline Maggi G.A. & 0 & 0 & 0 & 1 & 0 & 0 & 37 & Mathematical physics \\
\hline Marcolongo R. & 0 & 0 & 0 & 0 & 4 & $6+5 \mathrm{BF}$ & $>50$ & Mathematical physics \\
\hline Marletta G. & 0 & 2 & 0 & 12 & 1 & 17 & 13 & Geometry \\
\hline Marseglia N. & 0 & 1 & 0 & 0 & 0 & 0 & 0 & Elementary mathematics \\
\hline Martinetti V. & 0 & 0 & 0 & 1 & 2 & 6 & 16 & Geometry \\
\hline Mineo C. & 0 & 0 & 0 & 1 & 0 & 3 & 12 & Mathematical physics \\
\hline
\end{tabular}




\begin{tabular}{|l|l|l|l|l|l|l|l|l|}
\hline Mollame V. & 0 & 0 & 0 & 5 & 0 & 0 & 11 & Analysis \\
\hline Morale M. & 0 & 0 & 0 & 1 & 0 & 1 & 4 & Geometry \\
\hline Occhipinti R. & 0 & 0 & 0 & 1 & 0 & 2 & 24 & Geometry \\
\hline Orlando L. & 0 & 0 & 0 & 0 & 3 & 8 & $>50$ & Mathematical physics \\
\hline Pennacchietti G. & 0 & 0 & 0 & 20 & 0 & 10 & 4 & Mathematical physics \\
\hline Pieri M. & 0 & 0 & 2 & 2 & 0 & 6 & 31 & Geometry \\
\hline Precchia M. & 0 & 0 & 0 & 2 & 0 & 0 & 0 & Geometry \\
\hline Ragonesi S. & 1 & 0 & 0 & 0 & 0 & 0 & 0 & Geometry \\
\hline Scaccianoce R. & 1 & 0 & 0 & 0 & 0 & 0 & 1 & Geometry \\
\hline Scorza G. & 0 & 0 & 0 & 2 & 0 & 10 & 35 & Geometry \\
\hline Severini C. & 0 & 0 & 2 & 16 & 0 & 7 & 21 & Analysis \\
\hline Tedesco G.C. & 0 & 0 & 0 & 1 & 0 & 1 & 0 & Geometry \\
\hline Vella S. & 0 & 0 & 0 & 1 & 0 & 0 & 0 & Algebra \\
\hline Vivanti G. & 0 & 0 & 0 & 0 & 2 & 26 & $>50$ & Analysis \\
\hline Zurria G. & 0 & 0 & 0 & 2 & 0 & 0 & 1 & Analysis \\
\hline
\end{tabular}

Abbreviations:

$\mathrm{AAD}=$ Atti dell'Accademia dei Dafnici di Acireale

$\mathrm{AAZ}=$ Atti e rendiconti dell'Accademia di scienza, lettere e arti dei Zelanti e PP. dello studio di Acireale $\mathrm{BAG}=$ Bollettino delle Sedute dell'Accademia Gioenia di scienze naturali

$\mathrm{AAG}=$ Atti dell'Accademia Gioenia di scienze naturali

AAP $=$ Atti dell'Accademia Peloritana dei Pericolanti

RCMP = Rendiconti del Circolo Matematico di Palermo 


\section{Annex 3}

Number of mathematical papers published in the Atti of Sicilian academies in significant time periods

\begin{tabular}{|l|l|l|l|l|l|}
\hline Years & AAG & BAG & AAD & AAZ & AAP \\
\hline $1881-1885$ & 5 & 0 & 0 & 0 & 0 \\
\hline $1886-1890$ & 5 & 0 & 0 & 1 & 0 \\
\hline $1891-1895$ & 15 & 0 & 0 & 1 & 0 \\
\hline $1896-1900$ & 6 & 0 & 1 & 1 & 3 \\
\hline $1901-1908$ & 29 & 7 & 0 & 3 & 14 \\
\hline $1909-1914$ & 20 & 2 & 1 & 1 & 0 \\
\hline $1915-1920$ & 34 & 0 & 1 & 4 & 2 \\
\hline
\end{tabular}

Abbreviations:

$\mathrm{AAD}=$ Atti dell'Accademia dei Dafnici di Acireale

$\mathrm{AAZ}=$ Atti e rendiconti dell'Accademia di scienza, lettere e arti dei Zelanti e PP. dello studio di Acireale

$\mathrm{BAG}=$ Bollettino delle Sedute dell'Accademia Gioenia di scienze naturali

$\mathrm{AAG}=$ Atti dell'Accademia Gioenia di scienze naturali

AAP $=$ Atti dell'Accademia Peloritana dei Pericolanti 